\title{
Marine Biotechnology: Developments and Perspectives
}

\section{Francesco Buonocore*}

Department for Innovation in Biological, Agro-food and Forest systems, University of Tuscia, Largo dell'Università, Italy

Marine biotechnology (or blue biotechnology) is considered an area of great interest and potential due to the contribution for the building of a eco-sustainable and highly efficient society. The aquatic environments are still not fully explored and their resources could play an important role for various industrial activities. Different research priorities could be identified in the field on marine biotechnology to show the vision of the developments and perspectives for the next few years. A fundamental aspect is related to aquaculture: new methodologies will help in selective breeding of species, in increasing sustainability of production and in enhancing animal welfare, including changes in food supply, preventive therapeutic measures and use of zero-waste recirculation systems [1-3]. Moreover, aquaculture products will be improved to gain optimal nutritional properties for human health [4]. Another strategic area of marine biotechnology is related to the development of renewable energy products and processes, mainly using marine algae [5-8]. In addition, marine environment is a largely untapped source of novel compounds that could be potentially used as novel drugs, health, nutraceuticals and personal care products [6,9-12]. One of the main examples of a novel drug is the trabectedin, a marine compound first extracted from the marine tunicate Ecteinascidia turbinata which is at the basis of the anti-cancer drug Yondelis ${ }^{\circ}$. This product is actually used for the treatment of soft tissue sarcoma and ovarian cancer and is produced in an economically sustainable semisynthetic process. The carotenoid astaxanthin, an antioxidant pigment produced by different microalgae, is instead an example of an high value compound obtained from marine resources.

Blue biotechnology could be further involved in address key environmental issues, like in bio-sensing technologies to allow in situ marine monitoring, in bioremediation and in developing cost-effective and non-toxic antifouling technologies [13-15]. Finally, marinederived molecules could be of high utility as industrial products or could be used in industrial processes as new enzymes, biopolymers and biomaterials [16-22]. Some example of products already in the market includes DNA ligase from Thermococcales, selected for their high fidelity, shrimp alkaline phosphatase (SAP), due to its heat inactivation properties, and green florescent protein (GFP) from Aequorea victoria.

In conclusion, marine biotechnology represents a pivotal sector to provide new useful tools for key societal challenges in the next future.

\section{References}

1. Melamed P, Gong Z, Fletcher G, Choy L, Hew CL (2002) The potential impact of modern biotechnology on fish aquaculture. Aquaculture 204: 255-269.

2. Adams A, Thompson KD (2006) Biotechnology offers revolution to fish health management. Trends Biotechnol 24: 201-205.

3. Tal Y, Schreier H, Sowers K, Stubblefield J, Place A, et al. (2009) Environmentally sustainable land-based marine aquaculture. Aquaculture 286: 28-35.

4. Adarme-Vega TC, Lim DK, Timmins M, Vernen F, Li Y, et al. (2012) Microalgal biofactories: a promising approach towards sustainable omega-3 fatty acid production. Microb Cell Fact 11: 96

5. Rosenberg JN, Oyler GA, Wilkinson L, Betenbaugh MJ (2008) A green light for engineered algae: redirecting metabolism to fuel a biotechnology revolution. Curr Opin Biotechnol 19: 430-436

6. Wijffels RH (2008) Potential of sponges and microalgae for marine biotechnology. Trends Biotechnol 26: 26-31.
7. Wijfels $\mathrm{RH}$, Barbosa MJ (2010) An outlook on microalgal biofuels. Science 329: 796-799.

8. Georgianna DR, Mayfield SP (2012) Exploiting diversity and synthetic biology for the production of algal biofuels. Nature 488: 329-335.

9. Kim SK, Ravichandran YD, Khan SB, Kim YT (2008) Prospective of the cosmeceuticals derived from marine organisms. Biotechnol Bioprocess Engin 13: 511-523.

10. Molinski TF, Dalisay DS, Lievens SL, Saludes JP (2009) Drug development from marine natural products. Nature Reviews: Drug Discovery 8: 69-85.

11. Schumacher M, Kelkel M, Dicato M, Diederich M (2011) Gold from the sea: marine compounds as inhibitors of the hallmarks of cancer. Biotechnol Adv 29: 531-547.

12. Sperstad SV, Haug T, Blencke HM, Styrvold OB, Li C, et al. (2011) Antimicrobial peptides from marine invertebrates: challenges and perspectives in marine antimicrobial peptide discovery. Biotechnol Adv 29: 519-530.

13. Bhadury P, Wright PC (2004) Exploitation of marine algae: biogenic compounds for potential antifouling applications. Planta 219: 561-578.

14. de Carvalho CC, Fernandes $P$ (2010) Production of metabolites as bacterial responses to the marine environment. Mar Drugs 8: 705-727.

15. Campas M, Garibo D, Prieto-Simon B (2012) Novel nanobiotechnological concepts in electrochemical biosensors for the analysis of toxins. Analyst 137: 1055-1067.

16. Manilla-Perez E, Lange AB, Hetzler S, Steinbuchel A (2010) Occurrence, production, and export of lipophilic compounds by hydrocarbonoclastic marine bacteria and their potential use to produce bulk chemicals from hydrocarbons. Appl Microbiol Biotechnol 86: 1693-1706.

17. Laurienzo P (2010) Marine polysaccharides in pharmaceutical applications: an overview. Mar Drugs 8: 2435-2465.

18. Zhang C, Kim SK (2010) Research and application of marine microbial enzymes: status and prospects. Mar Drugs 8: 1920-1934.

19. Kennedy J, O'Leary ND, Kiran GS, Morrissey GP, O'Gara F, et al. (2011) Functional metagenomic strategies for the discovery of novel enzymes and biosurfactants with biotechnological applications from marine ecosystems. J Appl Microbiol 111: 787-799.

20. Waidmann MS, Bleichrodt FS, Laslo T, Reidel CU (2011) Bacterial luciferase reporters: the Swiss army knife of molecular biology. Bioeng Bugs 2: 8-16.

21. Wei YH, Chen WC, Wu HS, Janarthanan OM (2011) Biodegradable and biocompatible biomaterial, polyhydroxybutyrate, produced by an indigenous Vibrio sp. BM-1 isolated from marine environment. Mar Drugs 9: 615-624.

22. Wang X, Schroder HC, Wiens M, Schlomaßcher U, Muller WE (2012) Biosilica: Molecular Biology, Biochemistry and Function in Demosponges as well as its Applied Aspects for Tissue Engineering. Adv Mar Biol 62: 231-271.

*Corresponding author: Dr. Francesco Buonocore, Department for Innovation in Biological, Agro-food and Forest systems (DIBAF), University of Tuscia Largo dell'Università s.n.c., I-01100 Viterbo, Italy, Tel : +39-0761-357644; Fax +39-0761-357111; E-mail: fbuono@unitus.it

Received December 18, 2012; Accepted December 19, 2012; Published December 29, 2012

Citation: Buonocore F (2013) Marine Biotechnology: Developments and Perspectives. J Aquac Res Development 4:e105 doi:10.4172/2155-9546.1000e105

Copyright: (c) 2013 Buonocore F. This is an open-access article distributed unde the terms of the Creative Commons Attribution License, which permits unrestricted use, distribution, and reproduction in any medium, provided the original author and source are credited. 